\title{
OCCURENCE OF HEXAVALENT CHROMIUM IN THE OPHIOLITE RELATED AQUIFERS OF LOYTRAKI AND SCHINOS AREAS
}

\author{
Pyrgaki K. ${ }^{1}$, Argyraki A. ${ }^{2}$, Kelepertzis E. ${ }^{2}$, Paraskevopoulou V. ${ }^{1}$, Botsou F. ${ }^{1}$, \\ Dassenakis E. ${ }^{1}$, Mitsis I. $^{2}$ and Skourtsos E. ${ }^{2}$ \\ ${ }^{I}$ National and Kapodistrian University of Athens, Faculty of Chemistry, 15784, University \\ Campus, Zografou, Greece, konstantinapyrgaki@gmail.com,vparark@chem.uoa.gr, \\ fbotsou@chem.uoa.gr,edasenak@chem.uoa.gr \\ ${ }^{2}$ National and Kapodistrian University of Athens, Faculty of Geology and Geoenvironement, \\ Panepistimiopolis Zographou 15784, Athens, Greece, email: argyraki@geol.uoa.gr, \\ kelepert@geol.uoa.gr,mitsis@geol.uoa.gr,eskourt@geol.uoa.gr
}

\begin{abstract}
The main objective of the present study is to assess Cr(VI) concentrations in groundwater and surface water of Loutraki and Schinos areas. Totally, 38 samples were collected from both areas from April to May 2015. Both surface water and groundwater are of bicarbonate-magnesium type $\left(\mathrm{Mg}^{-} \mathrm{HCO}_{3}{ }^{-}\right)$and present very high concentrations of $\mathrm{Mg}^{2+}$ (up to $266 \mathrm{mg} / \mathrm{L}$ ) whereas the $\mathrm{Cr}(\mathrm{VI})$ concentrations vary among the different water groups $(<1,6 \mu \mathrm{g} / \mathrm{L}-120 \mu \mathrm{g} / \mathrm{L})$. Only 2 out of 15 boreholes of Loutraki area have chromium concentrations above the permissible level for drinking water $(50 \mu \mathrm{g} / \mathrm{L}$ for $\mathrm{Cr}($ tot $))$ with the maximum $\mathrm{Cr}(\mathrm{VI})$ concentration being $74 \mu \mathrm{g} / \mathrm{L}$. In the area of Schinos, three wells have also high concentrations of $\mathrm{Cr}(\mathrm{VI})$ ranging from $40 \mu \mathrm{g} / \mathrm{L}$ to $120 \mu \mathrm{g} / \mathrm{L}$. The absence of industrial activity in both areas is indicative of the geogenic origin of $\mathrm{Cr}(\mathrm{VI})$ in groundwater which is probably related to the dissolution and oxidation of primary $\mathrm{Cr}$ bearing minerals derived from ophiolithic rocks of Geraneia Mountains.

Keywords: hydrogeochemistry, geogenic contamination, chromium mobility.
\end{abstract}

\section{Пєрí $\eta \psi \eta$}

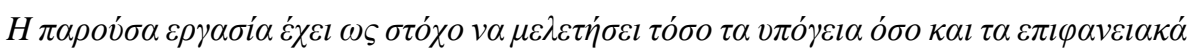

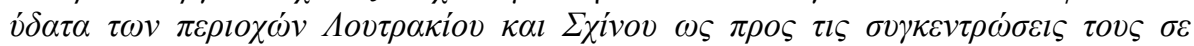

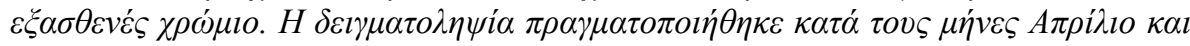

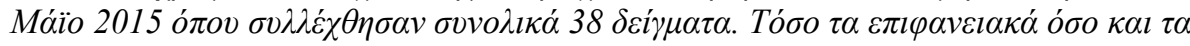

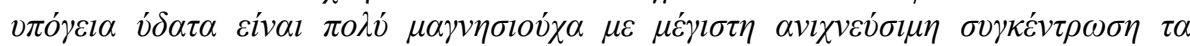

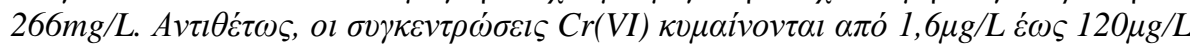

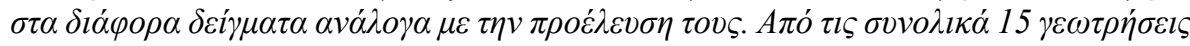

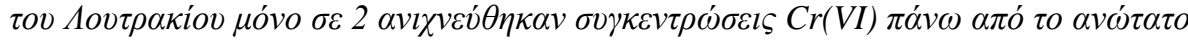

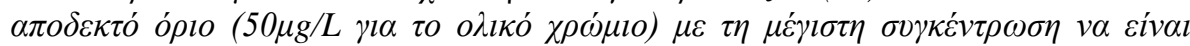

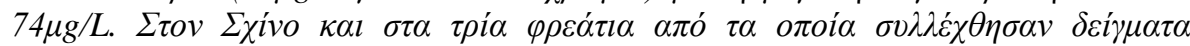

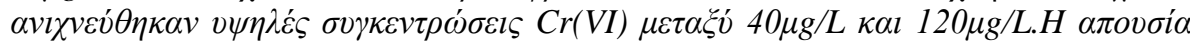

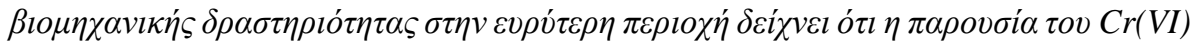




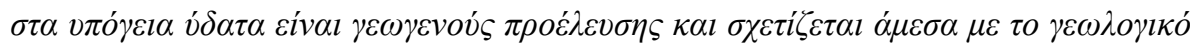

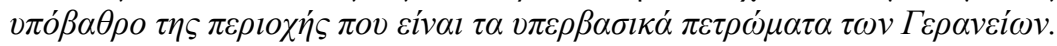

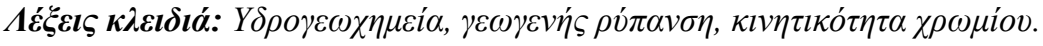

\section{Introduction}

Chromium occurs naturally but also enters the environment through emissions from human activities such as metallurgy and metal-finishing industries as well as from its use as a chemical intermediate. In water, chromium exists in two oxidation states, 3+ (III) and 6+ (VI), but the more thermodynamically stable state is $\mathrm{Cr}(\mathrm{VI})$. Hexavalent chromium is far more mobile than $\mathrm{Cr}(\mathrm{III})$ and more difficult to remove from water. It is also the toxic form of chromium, being approximately 10 to 100 times more toxic than $\mathrm{Cr}$ (III) by the acute oral route. Until recently human activities were considered the only $\mathrm{Cr}(\mathrm{VI})$ source in groundwater, however, latest research has shown that relatively high levels of $\mathrm{Cr}(\mathrm{VI})$ can also be attributed to natural processes (Kazakis et al., 2015; Dermatas et al. 2015; Megremi et al., 2013; Moraitis et al., 2012; Margiota et al., 2012; Oze et al. 2007; Fantoni et al., 2002). Weathering and erosion of ultramafic rocks are possibly the main responsible mechanisms for the mobility of chromium from the bedrock to soils and aquifers. According to the Water Framework Directive 2000/60/EC, the upper limit of Cr(tot) in drinking water is $50 \mu \mathrm{g} / \mathrm{L}$ for the countries of European Union including Greece. However, Italy has regulated a maximum permissible level of $\mathrm{Cr}(\mathrm{VI})$ in drinking water at $5 \mu \mathrm{g} / \mathrm{L}$.

Hexavalent chromium contamination in groundwater has been reported at several areas of Greece. Elevated concentrations have been attributed to natural processes within ophiolite related aquifers (Kazakis et al., 2015; Kaprara et al., 2015; Dermatas et al., 2015), anthropogenic activities in industrial zones such as the notorious case of the Oinofyta- Asopos groundwater contamination (Panagiotakis et al., 2015) or a combination of both, such as the ultramafic rock rich area of central Euboea which is also characterized by intensive agriculture (Voutsis et al., 2015; Megremi et al., 2013). Previously published data from the area of Schinos, which is one of study areas of the present study, reported high concentrations of $\mathrm{Cr}(\mathrm{VI})$ in a few domestic water wells within the village and attributed contamination to uncontrolled waste disposal (Papadopoulos and Lappas, 2014).

Taking into account that further study is required in order to assess $\mathrm{Cr}$ (VI) contamination in areas with suspect to geology, the objective of the present study is to present newly collected data regarding $\mathrm{Cr}(\mathrm{VI})$ concentrations in surface and groundwater samples from the area of Loutraki and Schinos and discuss $\mathrm{Cr}(\mathrm{VI})$ contamination in the context of the general hydrogeological and hydrogeochemical profile of the study areas.

\section{Materials and Methods}

\subsection{Study Areas}

The study areas (Loutraki and Schinos) are located in the Perachora peninsula at the eastern part of Corinthian Gulf (Fig.1). Loutraki lies at the southern part of Perachora peninsula and it is surrounded by the Gulf of Lechaio. The drainage basin of Loutraki covers an area of approximately $53.27 \mathrm{~km}^{2}$ and has a perimeter of $35 \mathrm{~km}$. The maximum elevation is $1068 \mathrm{~m}$ a.s.l. while the mean elevation is approximately $470 \mathrm{~m}$ a.s.l. The main geological formations of Loutraki's drainage basin are carbonate rocks (limestone) which cover an area of approximately $11.8 \mathrm{~km}^{2}$, ophiolitic rocks (peridotite and serpentinite) which cover an area of $20.4 \mathrm{~km}^{2}$, Neogene carbonate clay formations (marl) which cover an area of $1.1 \mathrm{~km}^{2}$, functioning as a barrier due to their impermeability controlling the groundwater flow and finally Quartenary conglomerate and alluvial deposits which cover an area of approximately $16 \mathrm{~km}^{2}$ (Bornovas et al.,1969). The above rock formations can be classified as permeable (limestone, quaternary conglomerates and alluvial deposits), partially permeable (marly sandstones and fractured ophiolites) and impervious (clay and marl). The main streams of Loutraki drainage network are Loumpiniaris and Agia Triada. The metallic aquifer is located in the alluvial 
deposits consisting of ophiolite material (mainly serpentinite and pyroxenite) from the weathering and erosion of the ophiolite complex of Geraneia Mountains and covers approximately an area of $7.45 \mathrm{~km}^{2}$ with a maximum depth level of water at $150 \mathrm{~m}$ (Kounis and Vitoriou, 2003a). The main sources of metallic groundwater are the direct infiltration of precipitation water, the runoff water of the whole drainage basin, the runoff water of ophiolite riverbeds from Geraneia Mountains as well as the underground source of conglomerates aquifer in the southeast part of Loutraki's drainage basin.

The area of Schinos is located in the northeastern part of Perachora peninsula and it is surrounded by the Alkyonides Gulf. The drainage area of Schinos covers approximately an area of $22,4 \mathrm{~km}^{2}$ where the main geological formations are Jurassic limestone which is heavily fractured and fissured due to alpine and post-alpine tectonic movements, the Boeotian flysch consisting of rhythmic series of sandstone, clastic limestone and chert, ophiolites (serpentinite and peridotite) and the schist-chert formation at the base of ophiolite mélange which consists of radiolarites containing thin Mn-layers and reddish or grey limestone with chert (Bornovas et al.,1979). The wider region of Pissia-Schinos is tectonically active with active normal faults of NW-SE and E-W directions and this is depicted at the geomorphology of the whole area with abrupt alternation of slopes. The upper post-alpine formations are alluvial deposits and talus cones where the Schinos aquifer occurs. The aquifer of Schinos is placed in scree for the upper $2 \mathrm{~m}$ depth and in fractured peridotites until a depth of $100 \mathrm{~m}$ approximately (Kounis and Vitoriou, 2003b). The quality of groundwater is low due to sea intrusion (Papadopoulos and Lappas, 2014) so it is used mainly for irrigation.

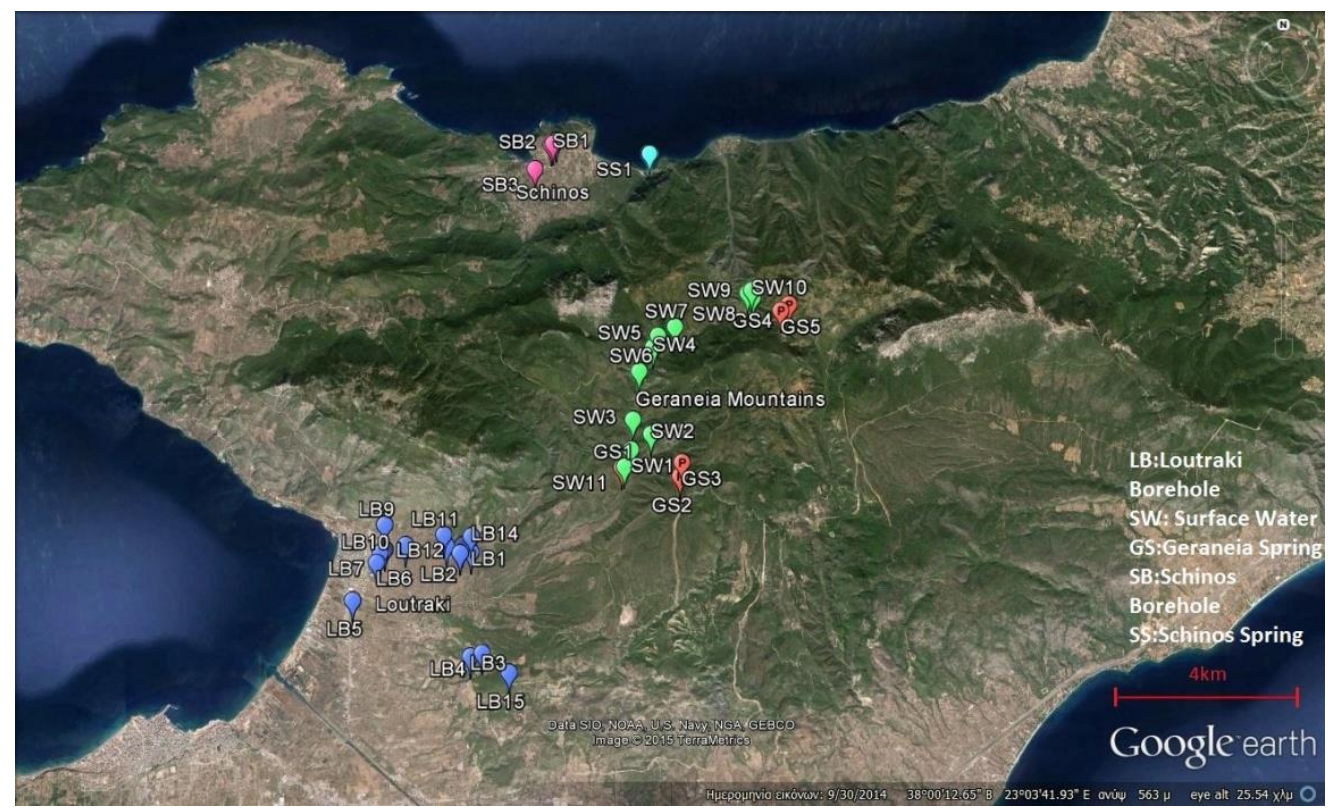

Figure 1 - Google earth map with sampling points. 

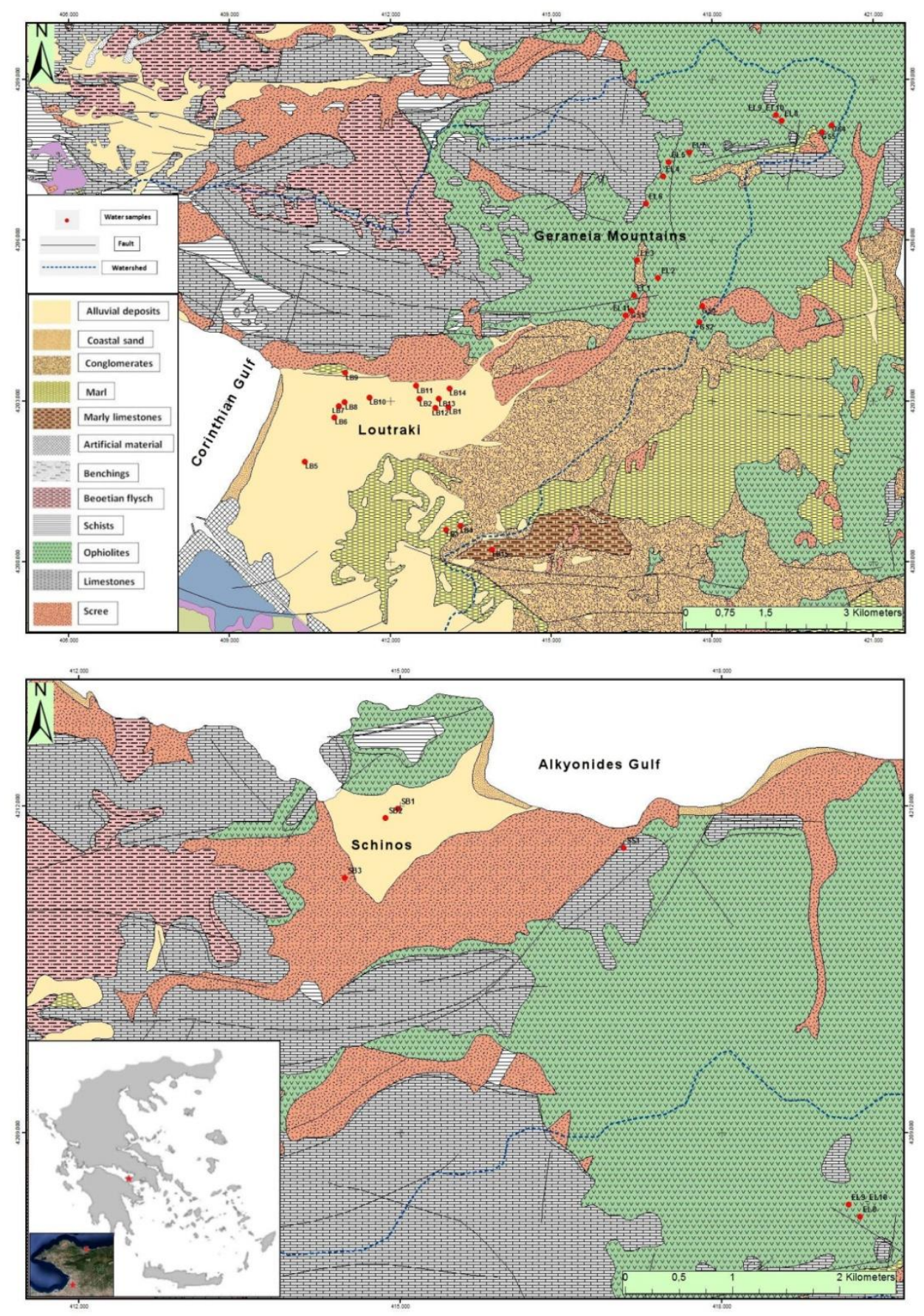

Figure 2 - Geological map of Loutraki and Schinos areas and location of sampling points. 


\subsection{Water Sampling and Analysis}

A total of 38 water samples were collected from April to May 2015 (Fig. 1). Groundwater samples were collected from 15 boreholes from Loutraki area (LB) used to cover mainly the drinking water demands of Loutraki's residents. In addition, 5 groundwater samples (GS) were collected from natural springs of Geraneia Mountains, 11 surface water samples from the streams of Geraneia Mountains (SW), 1 surface water sample from the area of Sousaki (SSW) and 6 from the area of Schinos including 3 samples from wells (SB), 2 from springs (SS) and 1 from a borehole (SBF). In each sampling station three sub-samples were collected in separate bottles; one for cation analysis, one for $\mathrm{Cr}(\mathrm{VI})$ analysis and one for anion analysis. The water samples for cation and $\mathrm{Cr}(\mathrm{VI})$ analysis were filtered through $0.45 \mu \mathrm{m}$ membrane filters in situ in order to collect only the soluble phases. The samples for cation analysis were acidified to $\mathrm{pH}<2$ by adding a few drops of $\mathrm{HNO}_{3}$. All samples were refrigerated during their transfer to laboratory. In situ measured parameters included $\mathrm{pH}$, electrical conductivity (EC), total dissolved solids (TDS) and temperature. All major ions and trace elements were analyzed shortly after sampling in the laboratories of Environmental Chemistry, and Economic Geology and Geochemistry, University of Athens. In particular, $\mathrm{Cr}(\mathrm{VI})$ was determined by the DPC colorimetric method according to the ELOT-EN-ISO 18412 Standard (2006). The absorbance was determined at $540 \mathrm{~nm}$ on a double beam UV-vis Carry 1E spectrophotometer. The Method's Detection Limit (MDL), determined according to the EPA CRF 40B procedure (EPA 2008), is $0.6 \mu \mathrm{g} \mathrm{L}^{-1}$. Nitric anions were measured with a photometric method which is based on the reduction of nitrates to nitrous using a cadmium column in a buffer solution and then the nitrous are measured according to the Griess-ilosvay process. Sodium and $\mathrm{K}^{+}$were determined by flame photometry, $\mathrm{Mg}^{2+}$ and $\mathrm{Ca}^{2+}$ were determined by means of Flame Atomic Adsorption Spectrometry (Varian SpectrAA-200) and finally the concentration of $\mathrm{HCO}_{3}^{-}$was calculated by measuring the alkalinity of the samples through titration with $\mathrm{H}_{2} \mathrm{SO}_{4} 1.16 \mathrm{~N}$ using a $\mathrm{HACH}$ digital titrator.

\section{Results and Discussion}

\subsection{Hydrogeochemical Features}

The chemical analyses were tested for charge balance errors. Calculated charge balance errors were found to be less than or equal to $\pm 10 \%$ for the majority of samples, which is an acceptable error for the purposes of the present study (Güler et al., 2002). Only 3 samples balance errors were above $\pm 10 \%$. In general, the different water samples are classified into 6 groups according to their type (springs, boreholes, surface water) and physicochemical properties (Table 1). Among the different groups, mean $\mathrm{pH}$ values range from 7.5 to 9 , conductivity (EC) ranges from 0.65 to $2.63 \mathrm{~ms} / \mathrm{cm}$, total dissolved solids (TDS) range from $0.33 \mathrm{~g} / \mathrm{L}$ to $1.34 \mathrm{~g} / \mathrm{L}$ and total hardness $\left(\mathrm{CaCO}_{3}\right)$ ranges from $329 \mathrm{mg} / \mathrm{L}$ to $606 \mathrm{mg} / \mathrm{L}$. Relatively elevated values of conductivity have been measured at a Loutraki borehole, LB5 $(13 \mathrm{mS} / \mathrm{cm})$ and at three Schinos boreholes-wells (SB1,SB2,SB3) ranging from 1.44 to $3.81 \mathrm{mS} / \mathrm{cm}$. These values are indicative of seawater intrusion because the same samples present elevated concentrations of $\mathrm{Na}^{+}$and $\mathrm{Cl}^{-}$. As is shown in Figure 3, most samples are characterised by high concentrations of $\mathrm{Mg}^{2+}$ exceeding $100 \mathrm{mg} / \mathrm{L}$ whereas $\mathrm{Ca}^{+}$concentrations are significantly lower, ranging from 2 to $40 \mathrm{mg} / \mathrm{L}$ for most samples.

As a result it is concluded that the groundwater as well as surface water chemical composition is directly influenced by their interaction with ultramafic rocks and serpentinites. This is also justified by the high ratios of $\mathrm{Mg} / \mathrm{Ca}$ for the different water groups (Table 1). The surface water samples (SW) are enriched in $\mathrm{Mg}^{2+}$ compared to Loutraki's alluvial aquifer groundwater (LB). The only sample with $\mathrm{Mg} / \mathrm{Ca}$ ratio below $1(0.15)$ is GS5 and this shows that probably this spring is related to the karstic aquifer. The highest $\mathrm{Mg} / \mathrm{Ca}$ ratio is 149 and characterizes the spring Prathi (GS4). Plotting the samples' composition on a Piper plot (Fig. 4) revealed that all water samples are of bicarbonate magnesium type $\left(\mathrm{Mg}-\mathrm{HCO}_{3}\right)$. Elevated concentrations of $\mathrm{NO}_{3}{ }^{-}$ranging from $16 \mathrm{mg} / \mathrm{L}$ to $207 \mathrm{mg} / \mathrm{L}$ have been detected in certain samples within the built areas of Loutraki (LB5) and Schinos 
(SB1,SB2,SB3) indicating most probably the deterioration of the water quality by wastewater i.e., contribution of organic effluents in water chemistry.

Table 1 - Mean values of physicochemical parameters and major ions in water samples.

\begin{tabular}{|c|c|c|c|c|c|c|c|c|c|c|c|}
\hline $\begin{array}{c}\text { Water } \\
\text { groups }\end{array}$ & $\mathbf{p H}$ & $\begin{array}{c}\mathbf{E C} \\
\mathbf{m s} / \mathbf{c m}\end{array}$ & $\begin{array}{c}\mathbf{T D S} \\
\mathbf{g} / \mathbf{L}\end{array}$ & $\begin{array}{c}\mathbf{C a}^{2+} \\
\mathbf{m g} / \mathbf{L}\end{array}$ & $\begin{array}{c}\mathbf{M g}^{2+} \\
\mathbf{m g} / \mathbf{L}\end{array}$ & $\mathbf{M g} / \mathbf{C a}$ & $\begin{array}{c}\mathbf{K}^{+} \\
\mathbf{m g} / \mathbf{L}\end{array}$ & $\begin{array}{c}\mathbf{N a}^{+} \\
\mathbf{m g} / \mathbf{L}\end{array}$ & $\begin{array}{c}\mathbf{H C O}^{-} \\
\mathbf{m g} / \mathbf{L}\end{array}$ & $\begin{array}{c}\mathbf{N O} \mathbf{3}^{-} \\
\mathbf{m g} / \mathbf{L}\end{array}$ & $\begin{array}{c}\mathbf{C r}(\mathbf{V I}) \\
\mathbf{\mu g} / \mathbf{L}\end{array}$ \\
\hline $\begin{array}{c}\text { LB } \\
(\mathrm{n}=15)\end{array}$ & 8.1 & 0.69 & 0.42 & 10.4 & 89.2 & 27.9 & 1.4 & 24.6 & 402 & 7.6 & 22.8 \\
\hline $\begin{array}{c}\text { GS } \\
(\mathrm{n}=5)\end{array}$ & 8.1 & 0.89 & 0.48 & 28 & 145 & 33.6 & 1.4 & 16.8 & 739 & 1.8 & 7.4 \\
\hline $\begin{array}{c}\mathrm{SW} \\
(\mathrm{n}=11)\end{array}$ & 8.6 & 0.69 & 0.35 & 20.2 & 126 & 26.5 & 1.2 & 17.3 & 660 & 3.1 & 1.8 \\
\hline $\begin{array}{c}\mathrm{SSW} \\
(\mathrm{n}=1)\end{array}$ & 8.3 & 1.1 & 0.54 & 35.8 & 145 & 6.7 & 1.5 & 27 & 825 & 1.3 & 3.5 \\
\hline $\begin{array}{c}\mathrm{SB} \\
(\mathrm{n}=3)\end{array}$ & 7.5 & 2.63 & 1.34 & 59.9 & 225 & 7 & 1.86 & 254 & 676 & 107 & 65.3 \\
\hline $\begin{array}{c}\mathrm{SS} \\
(\mathrm{n}=2)\end{array}$ & 9 & 0.65 & 0.33 & 2.07 & 105 & 55.3 & 1 & 20.6 & 580 & 1.3 & 1.3 \\
\hline
\end{tabular}

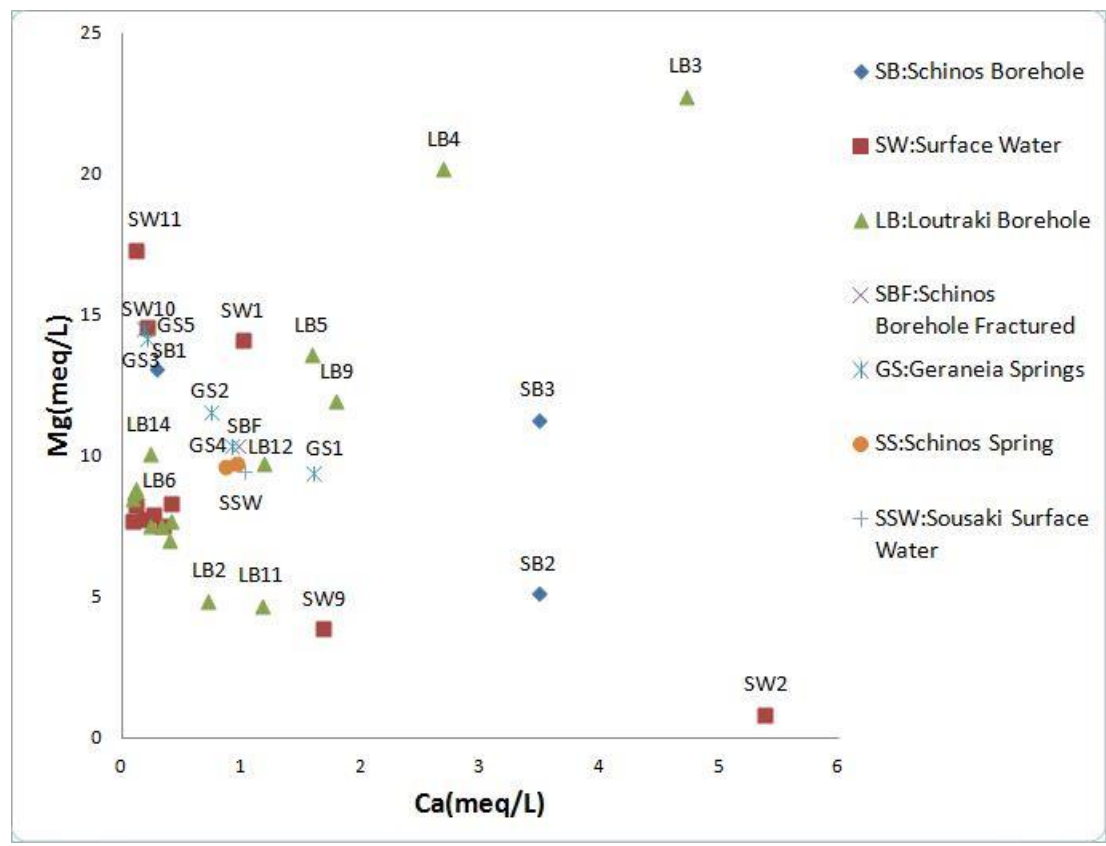

Figure 3 - Plot of Mg vs Ca. 


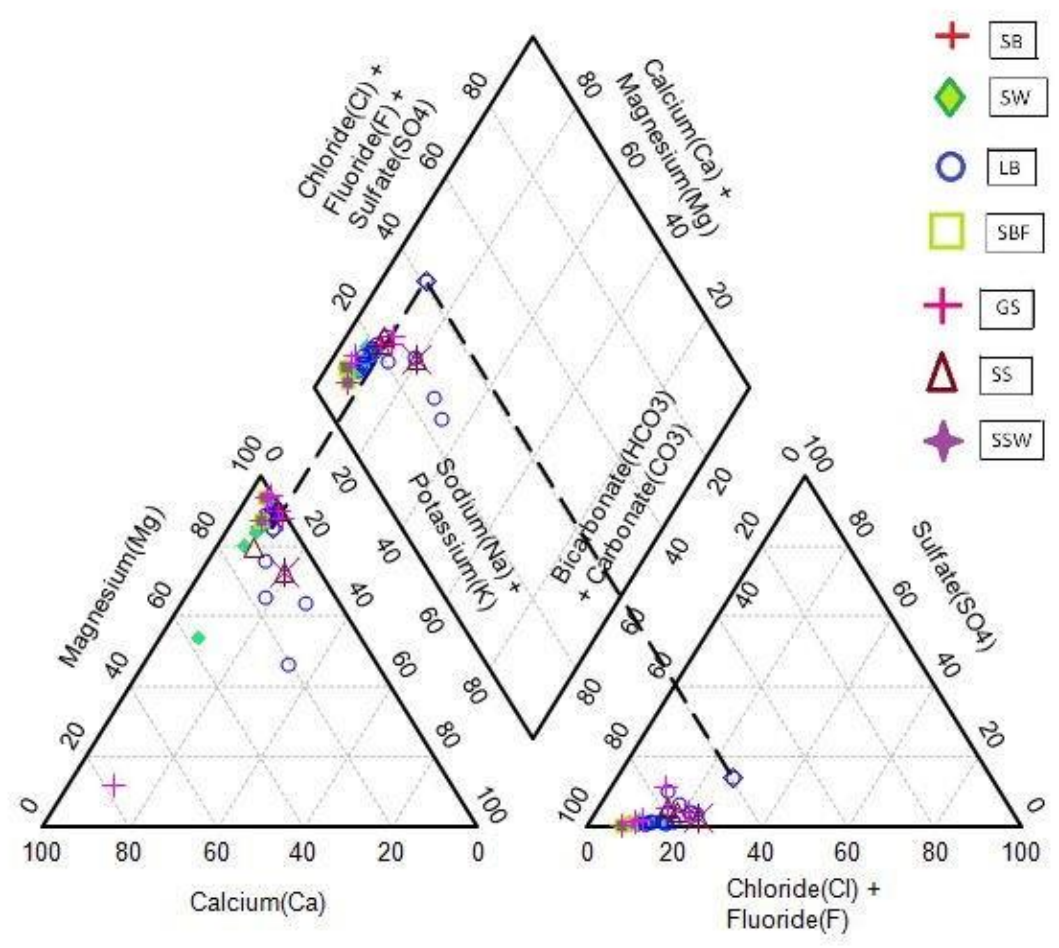

Figure 4 - Piper plot of different water groups indicating a bicarbonate magnesium water type.

\subsection{Occurrence of $\operatorname{Cr}(\mathrm{VI})$ in water}

The concentration of $\mathrm{Cr}(\mathrm{VI})$ in groundwater samples of Loutraki boreholes group (LB) were moderate to high ranging from $1.8 \mu \mathrm{g} / \mathrm{L}$ to $74 \mu \mathrm{g} / \mathrm{L}$ with a mean value of $23 \mu \mathrm{g} / \mathrm{L}$. Only 2 out of 15 samples had concentrations above the permissible level for drinking water. Dermatas et al. (2015) and Kazakis et al. (2015) have also found similar concentrations of $\mathrm{Cr}(\mathrm{VI})$ in the areas of Vergina (up to $64 \mu \mathrm{g} / \mathrm{L}$ ) and Anthemountas (up to $70 \mu \mathrm{g} / \mathrm{L}$ ) which also have an ophiolite-influenced geological background and aquifers which are related to ultramafic rocks. Furthermore, Dermatas et al. (2015) have reported much higher $\mathrm{Cr}(\mathrm{VI})$ concentrations, reaching $10 \mathrm{mg} / \mathrm{L}$ in groundwater from the area of Oinofyta where industrial activity is intense. The absence of industrial activities in the areas of Loutraki and Schinos as well as the concentrations levels of $\mathrm{Cr}(\mathrm{VI})$ are indicative of the natural source of this toxic element in water.

The highest $\mathrm{Cr}(\mathrm{VI})$ concentration of $120 \mu \mathrm{g} / \mathrm{L}$ was measured in one of the three water samples collected from domestic wells within the Schinos village. This is in agreement with data reported previously by Papadopoulos and Lappas (2014) who had measured up to $460 \mu \mathrm{g} / \mathrm{L} \mathrm{Cr}(\mathrm{VI})$ in a water well at Schinos village. In contrast to domestic water wells $\mathrm{Cr}(\mathrm{VI})$ concentrations in the borehole sample of the area (SBF) as well as the two springs SS1 and SS2 which are the drinking water sources of Schinos village did not exceed $1.85 \mu \mathrm{g} / \mathrm{L}$. Moderate concentrations have been found in Geraneia springs (GS) with a maximum value of $14 \mu \mathrm{g} / \mathrm{L} \mathrm{Cr}(\mathrm{VI})$ while low concentrations of $\mathrm{Cr}(\mathrm{VI})$ have been detected in surface water samples of Geraneia streams (SW) with a maximum concentration of approximately $4 \mu \mathrm{g} / \mathrm{L}$. The water samples with moderate to low concentrations of $\mathrm{Cr}(\mathrm{VI})(\mathrm{GS}, \mathrm{SW}, \mathrm{SBF}, \mathrm{SS})$ are related to the aquifer of fractured ultramafic rocks of Geraneia Mountains, whereas the water samples with higher concentrations (GL, BS) are related with Loutraki's and Schino's alluvial aquifers. It is noted that alluvial sediments consist mainly of eroded ophiolite material derived from the upland areas surrounding the plains (Fig. 2). The enrichment of 
alluvial aquifers in $\mathrm{Cr}(\mathrm{VI})$ has been also observed by Kazakis et al. (2015), Megremi et al. (2013) and Voutsis et al. (2015). Finally, Kelepertzis et al. (2013) have found that in Thiva basin which has a similar geological background, $\mathrm{Cr}$ (III) is mainly bounded within inherited chromite and to a lesser extent with $\mathrm{Cr}$-magnetite and $\mathrm{Cr}$ silicates like enstatite, a conclusion which is in accordance to recent observations for this study.

Figure 5 presents a plot of $\mathrm{Cr}(\mathrm{VI})$ against $\mathrm{Mg}^{2+}$ concentrations in water samples. It is obvious that the increase of soluble $\mathrm{Mg}^{2+}$ does not influence soluble $\mathrm{Cr}(\mathrm{VI})$. This is probably explained by different sources of the two elements i.e., olivine for $\mathrm{Mg}$ and chromite for $\mathrm{Cr}$ as well as different processes affecting their release into the water, i.e. congruent dissolution of olivine and other silicate minerals for $\mathrm{Mg}$ and release of $\mathrm{Cr}$ (III) from chromite with subsequent oxidation to $\mathrm{Cr}(\mathrm{VI})$. According to the literature the release of $\mathrm{Cr}(\mathrm{VI})$ in the aqueous environment depends on several parameters such as the redox potential, the presence of $\mathrm{MnO}_{2}$ and $\mathrm{Fe}_{2} \mathrm{O}_{3}$, the level of dissolved $\mathrm{O}_{2}$ etc. Manganese oxides are likely to be responsible for chromium oxidation in aquatic environments through the following reaction (Fendorf, 1995):

$\mathrm{Cr}(\mathrm{OH})^{2+}+1.5 \mathrm{MnO}_{2} \rightarrow \mathrm{HCrO}_{4}^{-}+1.5 \mathrm{Mn}^{2+}$

Also worth noting in Fig. 5 is the clustering of water samples according to their respective groups with stream water samples showing the lowest $\mathrm{Cr}(\mathrm{VI})$ concentrations and groundwater samples showing the highest $\mathrm{Cr}(\mathrm{VI})$ concentrations. This, indicates that the residence time of groundwater is a significant factor affecting $\mathrm{Cr}(\mathrm{VI})$ release into the water. Finally, the samples with relatively high conductivity (LB5,SB1,SB2,SB3) have also high concentrations of $\mathrm{Cr}(\mathrm{VI})$ ranging from $37 \mu \mathrm{g} / \mathrm{L}$ to $120 \mu \mathrm{g} / \mathrm{L}$.

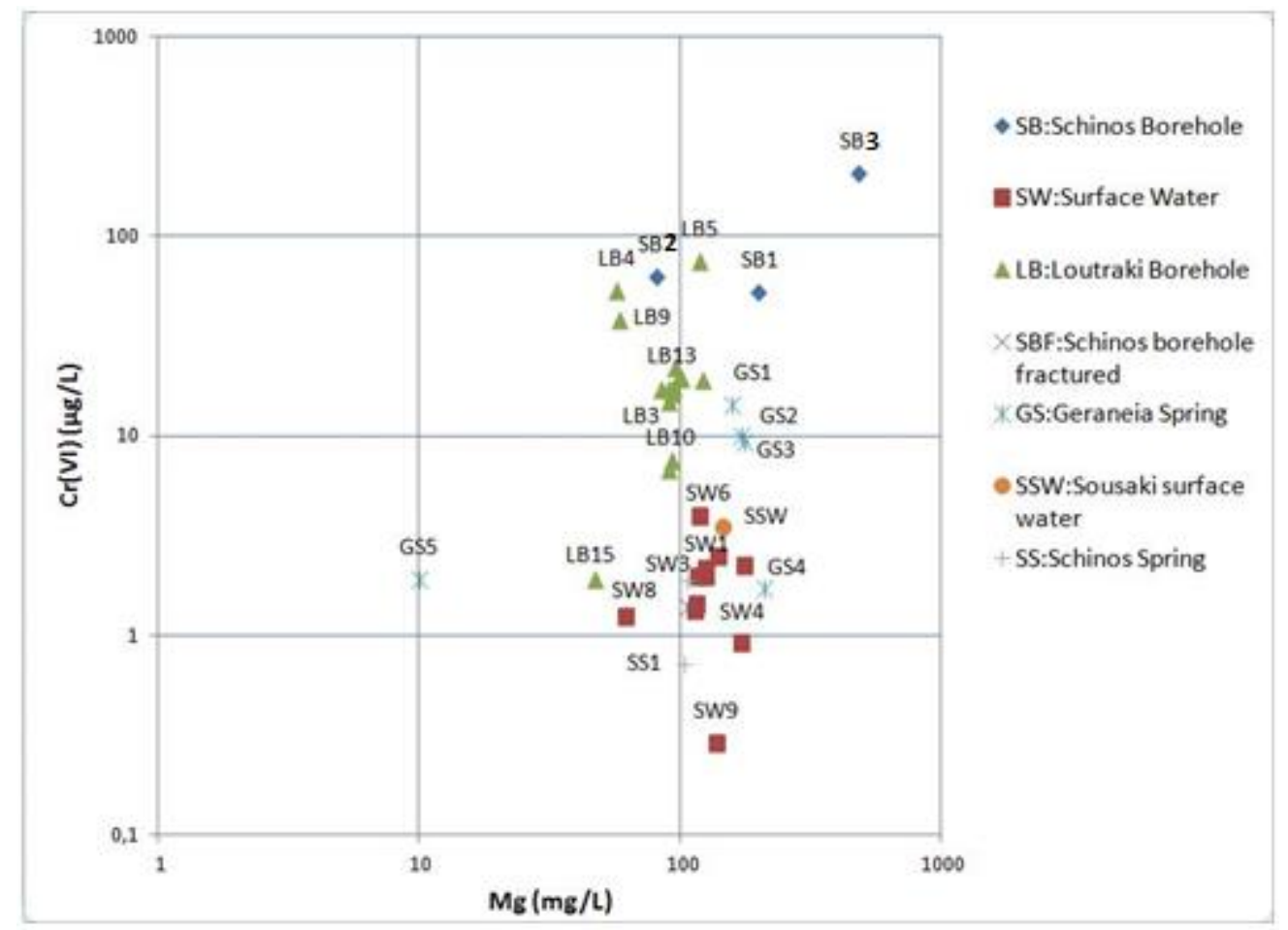

Figure 5 - Plot of Cr(VI) vs Mg. 


\section{Conclusions}

Hexavalent chromium contamination of surface and groundwater in the areas of Loutraki and Schinos has been accessed in the context of local geology and hydrogeochemistry. Based on the data presented in the previous paragraphs the following conclusions have been drawn:

- The general chemical composition of all water samples is of $\mathrm{Mg}^{-} \mathrm{HCO}_{3}$ type due to the interaction of both surface and groundwater with serpentinized ultramafic rocks that characterize the local geology.

- The release of $\mathrm{Cr}(\mathrm{VI})$ in groundwater is probably linked to natural processes and it is reflective of water-rock interaction within the ophiolite related aquifers in the study area.

- Alluvial aquifers present moderate to high concentrations of $\mathrm{Cr}(\mathrm{VI})$ in contrast to ophiolite fractured aquifers where the lowest $\mathrm{Cr}(\mathrm{VI})$ concentrations were measured.

- Groundwater of alluvial aquifers is enriched in $\mathrm{Mg}^{2+}$ and $\mathrm{Cr}(\mathrm{VI})$ in contrast to surface water which has only high concentrations of $\mathrm{Mg}^{2+}$.

- Groundwater samples with higher conductivity exhibit the highest concentrations of $\mathrm{Cr}(\mathrm{VI})$.

Further research, looking into the mineralogy and weathering regime of chromium bearing phases in the serpentinized rocks as well as the hydrogeological features at local scale is needed in order to clarify the processes affecting $\mathrm{Cr}(\mathrm{VI})$ release into the water.

\section{Acknowledgments}

The authors would like to thank the Director of the Municipal Enterprise for Water and Sewage (MEWS) of Loutraki - Agioi Theodoroi Mr. Anastasios Mastrantonakis as well as the technical staff of MEWS for providing access to the Municipal boreholes and their help during the sampling survey. The help during field sampling of $\mathrm{Mr}$ Ioannis Ligouthis is also acknowledged.Dr. Sotirios Karavoltsos of the Laboratory of Environmental Chemistry, University of Athens is thanked for his help during water sample analysis.

\section{References}

Bornovas, J.I., Eleutheriou, A. and Gaitanakis, P., 1970-1980. Map of IGME Kaparellion.

Bornovas, J., Lalechos, N. and Filippakis, N., 1969. Map of IGME Korinthos.

Dermatas, D., Mpouras, T., Chrysochoou, M., Panagiotakis, I., Vatseris, C., Linardos, N. and Sakellariou, L., 2015. Origin and concentration profile of chromium in a Greek aquifer, Journal of Hazardous Materials, 281, 35-46.

Fantoni, D., Brozzo, G., Canepa, M., Cipolli, F., Marini, L., Ottonello, G. and Zuccolini, M., 2002. Natural hexavalent chromium in groundwaters interacting with ophiolitic rocks, Environmental Geology, 42(8), 871-882.

Fendorf, S.E., 1995. Surface reactions of chromium in soils and waters, Geoderma, 67(1), 55-71.

Güler, C., Thyne, G.D., McCray, J.E. and Turner, K.A., 2002. Evaluation of graphical and multivariate statistical methods for classification of water chemistry data, Hydrogeology journal, 10(4), 455474.

Kaprara, E., Kazakis, N., Simeonidis, K., Coles, S., Zouboulis, A.I., Samaras, P. and Mitrakas, M., 2015. Occurrence of $\mathrm{Cr}$ (VI) in drinking water of Greece and relation to the geological background, Journal of hazardous materials, 281, 2-11.

Kazakis, N., Kantiranis, N., Voudouris, K.S., Mitrakas, M., Kaprara, E. and Pavlou, A., 2015. Geogenic $\mathrm{Cr}$ oxidation on the surface of mafic minerals and the hydrogeological conditions influencing hexavalent chromium concentrations in groundwater, Science of the Total Environment, 514, 224 238. 
Kelepertzis, E., Galanos, E. and Mitsis, I., 2013. Origin, mineral speciation and geochemical baseline mapping of $\mathrm{Ni}$ and $\mathrm{Cr}$ in agricultural topsoils of Thiva valley (central Greece), Journal of Geochemical Exploration, 125, 56-68.

Kounis, G. and Vitoriou-Georgouli, A., 2003a. Water balance of Loutraki'smetallic aquifer.

Kounis, G. and Vitoriou-Georgouli, A., 2003b. Hydrogeological survey of Schinos area with implementation of pumping tests.

Margiotta, S., Mongelli, G., Summa, V., Paternoster, M. and Fiore, S., 2012. Trace element distribution and $\mathrm{Cr}$ (VI) speciation in $\mathrm{Ca}-\mathrm{HCO} 3$ and $\mathrm{Mg}-\mathrm{HCO} 3$ spring waters from the northern sector of the Pollino massif, southern Italy, Journal of Geochemical Exploration, $115,1-12$.

Megremi, I., Vasilatos, C., Atsarou, A., Theodoratou, C., Economou-Eliopoulos, M. and Mitsis, I., 2013. Geochemical evidences for the sources of the $\mathrm{Cr}(\mathrm{VI})$ contamination in groundwater in central Euboea and Assopos-Thiva basins, Greece: natural versus anthropogenic origin, European Water, 41, 23-34.

Moraetis, D., Nikolaidis, N.P., Karatzas, G.P., Dokou, Z., Kalogerakis, N., Winkel, L.H.E. and Palaiogianni-Bellou, A., 2012. Origin and mobility of hexavalent chromium in North-Eastern Attica, Greece, Applied Geochemistry, 27(6), 1170-1178.

Oze, C., Bird, D.K. and Fendorf, S., 2007. Genesis of hexavalent chromium from natural sources in soil and groundwater, Proceedings of the National Academy of Sciences, 104(16), 6544-6549.

Panagiotakis, I., Dermatas, D., Vatseris, C., Chrysochoou, M., Papassiopi, N., Xenidis, A. and Vaxevanidou, K., 2015. Forensic investigation of a chromium (VI) groundwater plume in Thiva, Greece, Journal of Hazardous Materials, 281, 27-34.

Papadopoulos, K. and Lappas, I., 2014. Groundwater quality degradation due to $\mathrm{Cr}^{6+}$ presence in Schinos area, prefecture of Corinth, Central Greece, $10^{\text {th }}$ International Hydrogeological Congress of Greece, Thessaloniki.

Richard, F.C. and Bourg, A.C., 1991. Aqueous geochemistry of chromium: a review, Water Research, 25(7), 807-816.

Voutsis, N., Kelepertzis, E., Tziritis, E. and Kelepertsis, A., 2015. Assessing the hydrogeochemistry of groundwaters in ophiolite areas of Euboea Island, Greece, using multivariate statistical methods, Journal of Geochemical Exploration, 159, 79-92. 